READING COLUMBUS 


\title{
LATIN AMERICAN LITERATURE AND CULTURE
}

\author{
General Editor
}

Roberto González Echevarría

Bass Professor of Hispanic and Comparative Literatures Yale University

1. Manuel Bandeira, This Earth, That Sky, trans. Candace Slater

2. Nicolás Guillén, The Daily Daily, trans. Vera M. Kutzinski

3. Gwen Kirkpatrick, The Dissonant Legacy of Modernismo:

Lugones, Herrera y Reissig, and the Voices of Modern Spanish American Poetry

4. Pablo Neruda, Selected Odes of Pablo Neruda, trans. Margaret Sayers Peden

5. Rosamel del Valle, Eva the Fugitive, trans. Anna Balakian

6. Jean de Léry, History of a Voyage to the Land of Brazil, Otherwise Called America, trans. Janet Whatley

7. Pablo Neruda, Canto General, trans. Jack Schmitt

8. Doris Sommer, Foundational Fictions: The National Romances of Latin America

9. Margarita Zamora, Reading Columbus 


\section{READING COLUMBUS}

Margarita Zamora

University of California Press

Berkeley · Los Angeles · London 
The publisher gratefully acknowledges a grant from the Program for Cultural Cooperation between Spain's Ministry of Culture and United States Universities.

University of California Press

Berkeley and Los Angeles, California

University of California Press, Ltd.

London, England

C 1993 by

The Regents of the University of California

Library of Congress Cataloging-in-Publication Data

Zamora, Margarita.

Reading Columbus / Margarita Zamora.

p. $\quad \mathrm{cm}$. - (Latin American literature and culture ;9)

Includes bibliographical references and index.

ISBN 0-520-08052-I (alk. paper). — ISBN 0-520-08297-4 (pbk. : alk. paper)

1. Columbus, Christopher-Literary art.

2. America-Early accounts to $1600-$ History and criticism. I. Title. II. Series: Latin American literature and culture (Berkeley, Calif.) ; 9 .

$E_{112 . Z 35} 1993$

970.01'5-dc20

Printed in the United States of America

$\begin{array}{lllllllll}1 & 2 & 3 & 4 & 5 & 6 & 7 & 8 & 9\end{array}$

The paper used in this publication meets the minimum requirements of American National Standard for Information Sciences-Permanence of Paper for Printed Library Materials, ANSI Z39.48-1984. (-) 
In memory of

Juan Clemente Zamora y López-Silvero and

Rosario Munné y García de Andina 

Et convertat faciem suam ad insulas, et capiet multas.

And he shall turn his face to the islands and take many.

(Daniel 11:18a, as cited by Columbus,

Libro de las profecias) 
